\title{
PELATIHAN DASAR-DASAR MANAJEMEN PADA USAHA MIKRO KECIL MENENGAH (UMKM) KERIPIK PISANG DHARMA JAYA UNTUK MENINGKATKAN KINERJA USAHA
}

\author{
Novita Ekasari dan Suswita Roza \\ Jurusan Manajemen Fakultas Ekonomi Dan Bisnis Universitas Jambi \\ Email : ekasari.novita01@yahoo.com; susieroza@yahoo.com;
}

\begin{abstract}
ABSTRAK
Kegiatan pengabdian ini bertujuan untuk mengembangkan usaha kecil menengah (UKM) agar mampu mempertahankan usahanya dengan memberikan pengetahuan dasar manajemen yang terdiri atas manajemen pemasaran, manajemen keuangan dan manajemen sumber daya manusia sehingga usaha kecil menengah mampu mengelola usahanya secara internal maupun eksternal dengan baik, selain itu perngembangan usaha melalui media-media promosi terkini yang low budget perlu diketahui dan dipelajari oleh pemilik usaha sehingga tim juga akan berusaha untuk memberikan pengetahuan mengenai media promosi yang tepat untuk memperkenalkan dan memasarkan produk Darma Jaya baik secara online maupun offline, yang semuanya nanti akan diterjemahkan secara sederhana dan terperinci dalam satu model bisnis yang memuat kegiatan bisnis Darma Jaya mulai dari hulu ke hilir sehingga pemilik usaha bisa melihat apa yang sudah, sedang dan akan dilakukan oleh usaha Darma Jaya dengan Business Model Canvas (BMC). Pengabdian ini akan dilakukan melalui dua tahapan yaitu tahap perencanaan dan tahap pelaksanaan pengabdian. Hasil kegiatan pengabdian berupa deteksi permasalahan teknis yang terjadi dan pengetahuan manajemen dan teknis untuk mengatasi permasalahan tersebut, menerapkan metoda-metoda promosi baru yang belum pernah dilakukan oleh Darma Jaya serta pembuatan Business Model Canvas (BMC) untuk usaha Darma Jaya. Berdasarkan pelaksanaan,usaha Darma Jaya merupakan usaha menengah yang sedang berkembang dan memiliki prospek yang baik, dengan dilaksanakannya kegiatan ini maka usaha Darma Jaya dapat lebih kuat dan tertata dengan lebih baik lagi, pemilik mampu berfikir sistematis, manageable dan mengatasi masalah manajemen yang sebelumnya tidak bisa diatasi.
\end{abstract}

\section{Kata Kunci : Dasar Manajemen, Kinerja Usaha, UMKM}

\section{PENDAHULUAN}

Usaha mikro kecil dan menengah (UMKM) memiliki peranan yang sangat vital didalam pembangunan dan pertumbuhan ekonmi, tidak hanya dinegara-negara berkrmbang seperti indonesia tetapi juga di negara maju. Di indonesia peran UMKM selain berperan dalam pertumbuhan pembanguna dan ekonomi, UMKM juga memiliki peran yang sangat penting dalam mengatasi masalah pengangguran.

Melihat berbagai fakta di atas perkembangan UMKM memang tidak lepas dari peran pemerintah melalui kebijakan yang dikeluarkan terutama pada Undang-undang No. 20 tahun 2008 tentang Usaha Mikro Kecil dan Menangah. Di mana isinya terkait pengembangan UMKM yang dilakukan oleh pemerintah, pemerintah daerah, dunia usaha, dan masyarakat untuk memberdayakan UMKM melalui pemberian fasilitas, bimbingan, pendampingan, dan bantuan perkuatan untuk menumbuhkan dan meningkatkan kemampuan dan daya saing UMKM. Oleh karena UMKM perlu dikembangkan karena dapat menggerakkan laju 
pertumbuhan perekonomian Indonesia.Pentingnya peran dari usaha mikro kecil dan menengah dalam menggerakan ekonomi, mengurangi jumlah pengangguran.

Usaha industri ekonomi kratif di prediksi akan menjadi industri masa depan sebagai fourth wave industry ( industri gelombang keempat), yang menekankan pada ide kreatif. Hal ini bukan tanpa alasan, mengingat industri ekonomi kreatif telah mampu mengikat pasar dunia dengan jutaan kreativitas dan persepsi yang dijual secara global.

Salah satu UMKM yang ada di Provinsi Jambi adalah usaha keripik pisang Dharma Jaya . Dharma Jaya Snack sudah berdiri sejak tahun 2006 yang beralamat di RT 05 Kelurahan Lingkar Selatan, Kecamatan Jambi Selatan Kota Jambi. Usaha Dharma Jaya ini produknya terdiri dari keripik pisang dengan varian rasa sebagai produk utama, selain itu Dharma Jaya juga menjual produk-produk snack yang lainnya seperti keripik pisang, keripik buah nangka dan stik bawang dengan berbagai rasa. Keripik pisang Dharma Jaya sendiri sudah masuk ke dalam berbagai ritel yang ada di kota Jambi seperti Meranti, Jamtos, JPM Trona, Hypermart dan minimarket yang tersebar dikota Jambi, dengan jumlah karyawan yang terus meningkat dari hanya 1 karyawan menjadi 15 orang karyawan dengan memberdayakan ibu-ibu rumah tangga di sekitar lokasi produksi.

Keripik pisang Dharma Jaya merupakan salah satu produk food-baverages (makanan minuman) Usaha Kecil Menengah (UKM) unggulan. Pisang tanduk, bahan baku produk ini berukuran besar dengan rasa medium sweet dan hanya tumbuh di Jambi. Selain itu, untuk menjaga kualitas, Dharma Jaya memasok pisang langsung dari Kabupaten Tanjung Jabung Timur (Sabak) karena dikenal memiliki hasil pertanian berupa pisang yang berkualitas baik. Selain itu produk keripik pisang ini juga telah dikemas rapih dan bagus sesuai dengan standar penjualan snack yang beredar dipasaran dan bersertifikat halal serta telah mendapat izin dari BPOM dan Dinas Kesehatan Provinsi Jambi.

Dikarenakan usaha yang terus meningkat dan jumlah karyawan yang semakin banyak membuat pemilik mengalami masalah dalam mengatur terutama dari segi keuangan, pemasaran dan pengelolaan SDM. Pemilik walaupun pernah bekerja sebelum berwirausaha tetapi tidak memiliki pengetahuan manajemen yang mendalam sehingga pada saat usaha mulai besar mengalami kesulitan untuk memanage usaha tersebut, maka dari itulah tim merasa perlu adanya pelatihan dasar-dasar manajemen bagi pemilik agar mampu mengatur dan mengembangkan usahanya menjadi lebih baik lagi.

\section{TARGET DAN LUARAN}

\section{Tujuan Pengabdian}

Kegiatan Pengabdian yang dilakukan oleh tim pengabdian bertujuan untuk :

1. Memberikan pelatihan mengenai dasar-dasar manajemen baik pemasaran, keuangan sederhana dan Sumber Daya Manusia, dimana pemgetahuan manajemen pemasaran dasar meliputi pengetahuan tentang segmentasi pasar, menentukan target pasar dan positioning produk Darma Jaya di pasar .Pengetahuan dasar keuangan yang diberikan meliputi pengetahuan tentang laporan keuangan sederhana yang meliputi pembuatan neraca, laporan laba/rugi dan laporan perubahan modal.Pengetahuan Sumber Daya Manusia meliputi tentang pembagian kerja dan rekrutmen pegawai yang baik. 
2. Memberikan pemahaman lebih mendalam kepada pelaku usaha dalam promosi produk baik secara offline maupun secara online, dengan mengaktifkan kembali akun-akun media social dan pembuatan metode promosi berbiaya rendah seperti flyer yang ditempatkan di jalur keluar masuk pendatang /turis ke kota Jambi.

3. Membuat Bisnis Model Canvas (BMC) yang meliputi road map kegiatan Darma jaya secara sederhana sehingga terlihat apa yang sudah dilakukan dan prospek apa yang bisa dilakukan dimasa yang akan datang.

\section{METODE PELAKSANAAN}

\section{Kegiatan Pendahuluan}

Untuk menunjang kelancaran pelaksanaan pengabdian pada masyarakat berupa penyuluhan ini dilakukankan kegiatan awal yang mencakup:

a. Tahap Perencanaan

Pada tahap inikegiatan pengabdian yang akan dilaksanakan didahului dengan pembagian tugas di antara anggota kelompok, persiapan materi pelatihan, penetapan jadwal kegiatan pelatihan dan pendataan peserta pelatihan.

b. Tahap Persiapan

Pada tahap ini akan dilakukan konfirmasi kepada pemateri dan peserta pelatihan mengenai waktu dan tempat pelaksanaan kegiatan pelatihan.

\section{PelaksanaanKegiatan Pengabdian Pada Masyarakat}

Pengadian pada masyarakat ini dilakukan oleh tim dari Fakultas Ekonomi Universitas Jambi sebanyak 5 orang, yang terdiri atas 2 orang tim pengabdian yang dibantu oleh 3 orang mahasiswa.

1. Ketua : Novita Ekasari, SE, MM

2. Anggota : Suswita Roza, SE,MM

Kegiatan pengabdian telah dilaksanakan pada tanggal 14 oktober 2017 bertempat di rumah pemilik Dharma Jaya dan dilanjutkan dengan pendalaman pada pemilik di lokasi toko/showroom produk yang berlokasi di jalan adam malik no.25 Beringin Kota Jambi.

\section{Alur Kegiatan Pengabdian (Fishbone diagram)}

Pertumbuhan UMKM

Metode

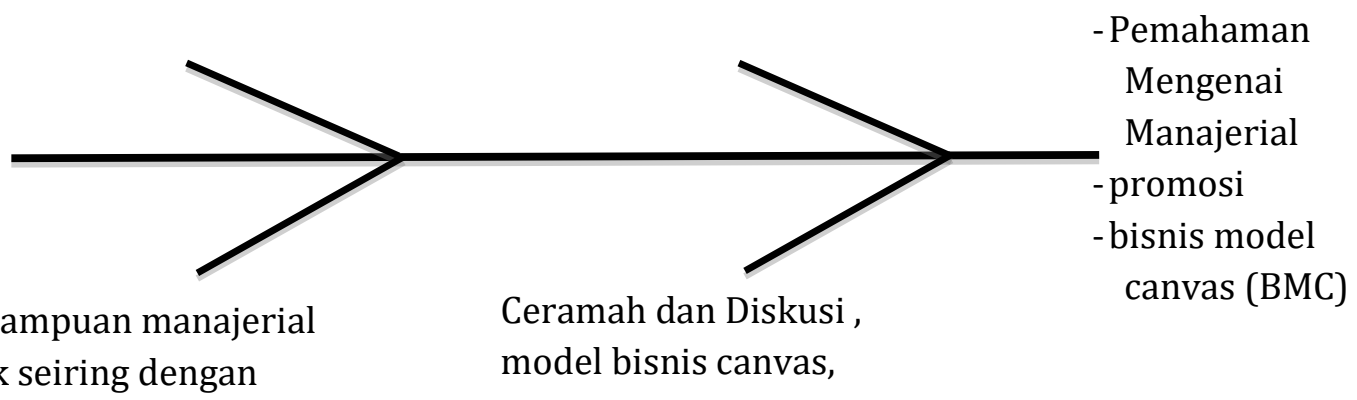

perkembangan usaha 


\section{Kelayakan Perguruan Tinggi \\ Kinerja Lembaga Pengabdian}

Lembaga Pengabdian Masyarakat Universitas Jambi yang bertugas untuk menyelenggarakan kegiatan pengabdian masyarakat yang berusaha untuk melakukan transfer pengetahuan, teknologi dan kesenian kepada masyarakat sesuai dengan kebutuhan masyarakat dalam satu tahun terakhir sudah melaksanakan berbagai kegiatan pengabdian masyarakat yang mana relevansi kegiatan yang diadakan menyebar ke berbagai lapisan masyarakat dengan beragam topic pelatihan dan kegiatan yang mampu menunjang keberlangsungan tidak hanya usaha tetapi masyarakat sebagai satu komunitas yang diberdayakan. Lembaga Pengabdian juga telah mengadakan Monitoring dan Evaluasi (MONEV) pengabdian masyarakat 2016 yang berlangsung pada 4 November 2016. Monitoring dan Evaluasi yang dilakukan menunjukkan bahwa lembaga pengabdian masyarakat universitas Jambi bekerja sesuai dengan fungsinya untuk memantau semua kegiatan pengabdian agar tepat sasaran dan tepat waktu.

\section{Jenis Kepakaran}

Pengetahuan dan keterampilan yang dibutuhkan dalam pelatihan ini adalah kemampuan teoritis dan teknis yang berhubungan dengan pemasaran (marketing), SDM dan keuangan yaitu tentang dasar-dasar manajemen agar kinerja usaha menjadi lebih baik dan produktivitas serta laba diharapkan dapat meningkat.

\section{HASIL YANG DICAPAI}

\section{Hasil dan Luaran}

Hasil dan Luaran yang telah dicapai selama pelaksanaan proses pengabdian yaitu:

1. Pelatihan dasar-dasar manajemen telah diberikan oleh tim pengabdian kepada mitra yang meliputi dasar-dasar mengenai manajemen pemasaran, manajemen keuangan, manajemen SDM dan manajemen operasional yang disesuaikan dengan kondisi mitra. Dari hasil pelatihan dan diskusi dengan pihak mitra dapat diketahui bahwa mitra telah menerapkan dasar-dasar manajemen ini hanya saja belum terlalu mendetail sehingga pengetahuan mitra ditambah melalui pelatihan ini. Seperti contohnya dalam manajemen pemasaran mitra belum menerapkan metode promosi yang menyeluruh sehingga masih banyak konsumen potensial yang belum mengetahui keberadaan gerai oleh-oleh khas jambi Dharma Jaya ini sehingga banyak potensial customer yang seharusnya bisa didapatkan menjadi hilang. Begitu juga dengan packaging atau kemasan masih ada beberapa produk yang belum dikemas dengan baik sehingga cepat rusak seperti kerupuk dan keripik yang menjadi cepat lempem dengan metode sharing tools dengan UMKM lain yang menitipkan produk di gerai Darma Jaya.

2. Pelatihan mengenai media-media promosi baik online maupun offline juga tim berikan kepada pihak mitra walaupun sebenarnya mitra sudah menerapkan system promosi melalui media social tetapi dari hasil analisis situasi diketahui penjulan offline tetap lebih tinggi dibandingkan online tetapi model promosi offline belum dilakukan secara maksimal, tim mencoba menerapkan model promosi offline melalui bentuk flyer kecil yang mitra titipkan pada pihak hotel, restaurant, bandara, po bus dalam dan luar kota dimana diharapkan dapat diperoleh konsumen potensial yang membutuhkan oleh-oleh 
khas Jambi yang bisa mengarahkan mereka untuk mengunjungi gerai produk dharma jaya.

3. Pembuatan Bisnis Model Canvas (BMC) diperlukan oleh usaha kecil menengah dimana metode ini sederhana untuk memetakan bisnis atau usaha. Tim mengajarkan BMC agar mitra dapat memetakan usaha dengan cara yang sederhana sehingga dapat terlihat apa yang sudah dicapai atau yang belum dan ingin dicapai oleh mitra dimasa yang akan datang. Model BMC dharma Jaya ada pada lampiran.

\section{KESIMPULAN DAN SARAN \\ Kesimpulan}

Kegiatan Pengabdian Kepada Masyarakat telah dilaksanakan pada tanggal 14 oktober 2017 dan telah melaksanakan seluruh target kegiatan yang direncanakan, yaitu :

a. Melaksanakan pelatihan dasar-dasar manajemen untuk mitra pengabdian yaitu UKM Keripik Pisang Dharma Jaya yang berlokasi di kelurahan Lingkar Selatan Kecamatan Jambi Selatan Kota Jambi, yang dihadiri oleh 10 orang yang terdiri dari pemilik dan karyawan PD.Darma Jaya.

b. Melaksanakan kegiatan pelatihan pemasaran melalui media online dan offline dan telah melakukan kegitan yang merupakan masukan yaitu menyebarkan informasi melalui media flyer yang berbiaya murah tapi diharapkan dampaknya tinggi (low budget high impact), mengaktifkan kembali penjulanan melalui media social yang kurang dikelola dengan intensif akhir-akhir ini.

c. Membuat Bisnis Model Canvas (BMC) untuk memetakan kegiatan usaha mitra agar terlihat road map usaha dalam satu model yang lengkap dan simple.

\section{Saran}

a. Berdasarkan hasil pengamatan tim terlihat bahwa usaha mitra telah mulai meningkat dari usaha kecil ke golongan menengah sehingga perlu adanya pebaikan pada manajemen usaha terutama pada system penggajian dimana pesanan mulai banyak dan teratur sehingga system penggajian bulanan menurut tim akan lebih menguntungkan dibandingkan harian atau mingguan.

b. Melakukan promosi secara aktif terutama di sentra-sentra titik masuk pendatang seperti bandara, hotel-hotel dan stasiun atau loket kendaraan dalam kota maupun luar provinsi.

c. Memperbaiki packaging dengan menggunakan kemasan yang lebih tahan lama, jika teknologinya butuh investasi besar bisa melakukan kerjasama atau sharing dengan UKM lain yang menitipkan produk (konsinyasi) di gerai Dharma Jaya sehingga saling menguntungkan.

\section{DAFTAR PUSTAKA}

Teuku Syarif (2015). Kajian Efektivitas Model Promosi Pemasaran Produk UMKM. Jurnal Kajian Bidang Penelitian UMKM.

Affandi, (1984). Manajemen Promosi dan Pemasaran Produk. PT. Bina Aksara. Jakarta.

Harry.R. Tosdal, (1969). Introduction to Sales Mangement. Mac Graw Hill Book Company New York. 
Jurnal Karya Abdi Masyarakat

Volume 2 Nomor 1 Januari - Juni 2018

Kasali Reinald, (2005). Tantangan Pemasaran Dalam Era Pasar Global (makalah yang disampaikan dalam Seminar sehari Penggembangan Pemasaran Industri Kerajinan Dalam Menghadapi Pasar Global).Program Magister Manajemen Universitas Indonesia. Jakarta.

Manulang, (1984). Marketing. Bharata. Jakarta.

Nurachmat, (2002). Kajian Manfaat Pameran dalam Meningkatkan Omset Industri kecil (Thesis). Program Pasca Sarjana Universitas Padjajaran Bandung. 